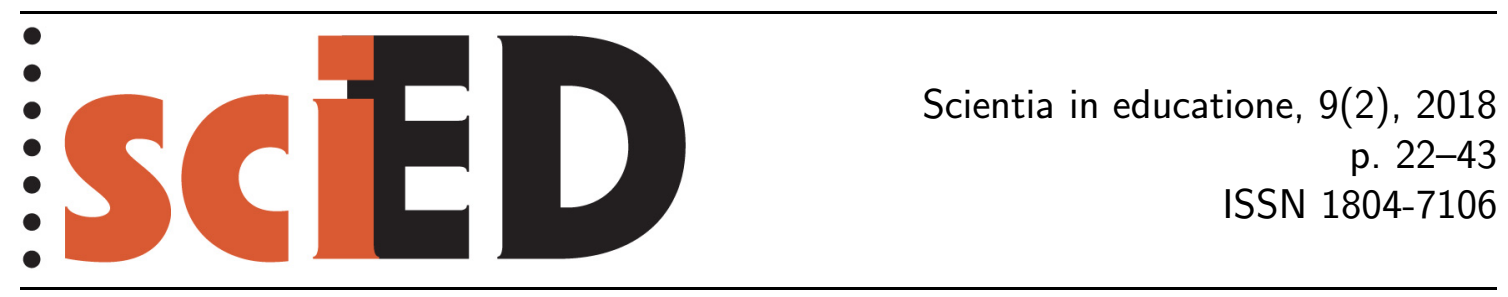

\title{
Miskoncepce žáků o atomech v kontextu představ starověkých myslitelů o stavbě hmoty
}

\author{
Eva Hejnová, Dalibor Hejna
}

\begin{abstract}
Abstrakt
V přehledové studii prezentujeme nejčastější miskoncepce v oblasti atomistiky, které byly odhaleny v zahraničních výzkumech. Četnost výskytu těchto miskoncepcí ilustrujeme na př́kkladu výzkumu představ o atomech, který jsme provedli v Ceské republice na souboru 170 žáků 9. ročníků z šesti základních škol a jedné kvarty víceletého gymnázia. Zároveň ukazujeme paralely některých miskoncepcí k představám starověkých myslitelů, přičemž se podrobněji zaměřujeme zejména na řecké atomisty. Na jejich myšlení chceme také ukázat, jak je znalost utváření historických předvědeckých teorií důležitá pro pochopení toho, jak pracuje současná věda a na jakém paradigmatu je založena.
\end{abstract}

Klíčová slova: stavba hmoty, atomismus, předvědecké teorie, miskoncepce.

\section{Pupils' Misconceptions about Atoms Juxtaposed to the Structure of Matter as Imagined by Ancient Thinkers}

\begin{abstract}
In this review study, we present the most common misconceptions about atoms that have been identified in foreign research. The frequency of these misconceptions is exemplified by a study we carried out in the Czech Republic, involving a set of 170 pupils consisting of one class of fourth graders at an eight-year grammar school and six classes of ninth graders from various basic schools, all of whom were quizzed on their understanding of atoms. At the same time, we show how some of their misconceptions parallel those of ancient thinkers, focusing in particular on Greek atomists. By shedding light on their thought processes, we also want to show how the knowledge of the formation of historical pre-scientific theories is important for understanding how contemporary science works and what paradigm it is based on.
\end{abstract}

Key words: structure of matter, atomism, pre-scientific theories, misconceptions. 
Intuitivní představy žáků v oblasti stavby hmoty byly předmětem již mnoha, zejména zahraničních, výzkumů (Griffiths \& Preston, 1992; Harrison \& Treagust, 1996; Driver et al., 2003; Stepans, 2003; Unver \& Arabacioglu, 2015). V České republice bylo výzkumům miskoncepcí v této oblasti dosud věnováno jen několik výzkumů (Škoda \& Doulík, 2006; Maunová, 2010 atd.), které se ale vesměs zaměřovaly pouze na vybrané aspekty této problematiky. Přitom mnohé miskoncepce týkající se pojmu atomu jsou rozššřené nejenom mezi žáky základních a středních škol, ale lze se s nimi setkat i u studentů vysokých škol (Ayas et al., 2010; Karataş et al., 2013). Ve vzdělávací praxi navíc není často jednoduché volit takové vyučovací postupy, které by k vytváření a dalšímu upevňování chybných představ nepřispívaly.

Atom je pojem, se kterým se žáci setkávají jak ve fyzice, tak v chemii; částicová stavba látek je součástí učiva vzdělávacího oboru fyzika i vzdělávacího oboru chemie (RVP ZV, 2016: s. 63, 68). Obtížnost výkladu tohoto pojmu spočívá v tom, že jde o značně abstraktní konstrukt: atom nelze vnímat lidskými smysly a nelze ho vidět ani pomocí jednoduchých přístrojů (např. pomocí lupy nebo mikroskopu). Při výkladu pojmu atom proto učitelé používají různé, více či méně vhodné modely, analogie a metafory (např. elektronový oblak, „rozmazaný“ elektron apod.). Žáci si však často vytvářejí své vlastní modely a jejich představy se tak mohou značně lišit od představy atomu, kterou se jim snaží předat jejich učitelé.

Atom bývá také uváděn jako jeden $\mathrm{z}$ př́kladů, jak se historicky $\mathrm{k}$ takovému pojmu dospělo na základě nepřímých usuzování (Maunová, 2010). Postup, jak k tomuto pojmu dospěli řečtí atomisté, je však zásadně odlišný od postupu současné moderní vědy. Zatímco u prvních atomistů a později i u filozofů a fyziků v 16. a 17. století se jednalo o výsledek ryze spekulativních úvah, moderní věda vychází zejména z experimentálních výsledků a její dokazování je založeno na zcela jiných postupech (Chalmers, 2009). Současná kvantově-mechanická představa atomu se zásadně liší od představ prvních atomistů i novověkých mechanistických filozofů, mezi něž patřil např. Gassendi a Boyle, a nelze mezi nimi tudíž hledat žádné analogie. Nicméně uvědomění si rozdílů mezi těmito zcela rozdílnými přístupy je důležité pro pochopení toho, jak pracuje současná věda.

Atomová hypotéza, tj. že se všechny věci skládají z atomů, které jsou v neustálém pohybu a vzájemně se přitahují, jestliže jsou od sebe v určité vzdálenosti, a odpuzují se, když jsou těsně u sebe, bezesporu patří mezi současné nejdůležitější vědecké poznatky (Feynman et al., 2000). Proto má atomismus významné postavení i ve školním kurikulu. Učitelé při výkladu částicové stavby látek často odkazují na starověký řecký atomismus, protože je v základní myšlence, tj. hmota má částicovou strukturu, podobná moderní atomové teorii. Při tom je však důležité mít na zřeteli, že antická př́rodní filozofie není jakási nezralá forma nebo předchůdkyně moderní př́rodní vědy, nebot čistě spekulativní filozofie žádnou vědou v dnešním chápání nebyla a ani nemohla být.

Nicméně mnohé, často frekventované miskoncepce vztahující se k pojmu atom vykazují paralelu k historickému vývoji tohoto pojmu (Griffiths \& Preston, 1992). Učitelé např́iklad často využívají zjednodušenou představu atomu jako tuhé kuličky, která lépe odpovídá schopnostem dětí takovou představu přijmout. V elementární výuce př́rodovědy je myšlenka, že částice jsou jako makroskopické tuhé materiální objekty, jen mnohem menší, akceptována, ne protože to odráží moderní vědecké představy, ale poněvadž tomu mohou děti jednodušeji porozumět. Díky jednoduchosti této představy si ji však mnozí lidé drží až do dospělého věku, a to i navzdory výuce atomové a jaderné fyziky, kterou absolvují na základní nebo střední škole. Důvodem bývá to, že předkládané poznatky jsou značně abstraktní, vzdálené běžné 
lidské zkušenosti; navíc se často v minimální míře opírají o experimentální důkazy (Lacina, 2011).

V naší přehledové studii chceme ukázat některé paralely nejčastějších miskoncepcí v oblasti atomistiky a představ starověkých myslitelů. Domníváme se, že znalost historického kontextu je důležitá pro pochopení prvotních prekoncepcí dětí, které si přirozeně vytvářejí o svém okolním světě. Na př́ikladu vývoje pojmu atomu lze zároveň jedinečným způsobem ukázat, jak je znalost utváření historických předvědeckých teorií důležitá pro pochopení toho, jak funguje současná věda a na jakém paradigmatu je založena. Výsledky této studie využijí s ohledem na mezioborový přesah učitelé fyziky, chemie i biologie na základních, středních i vysokých školách a zajímavý bude i pro didaktiky př́rodovědných předmětů.

$\mathrm{V}$ kapitole 1 nejprve předkládáme přehled představ nejznámějších myslitelů o stavbě hmoty, přičemž se podrobněji zaměřujeme zejména na řecké atomisty. V kapitole 2 pak prezentujeme nejčastější miskoncepce týkající se pojmu atom, které byly odhaleny v zahraničních výzkumech. Četnost výskytu těchto miskoncepcí pak ilustrujeme na př́kladu výzkumu představ o atomech, který jsme provedli v České republice na souboru 170 žáků 9. ročníků z šesti základních škol a jedné kvarty víceletého gymnázia.

Miskoncepcemi jsou obvykle míněny představy, které jsou v rozporu s vědeckými poznatky, jež si děti vytvářejí na základě svých zkušeností s okolním světem (Mandíková \& Trna, 2011). V kontextu problematiky řešené v naší studii je třeba poznamenat, že představy o atomu a jeho stavbě si žáci vytvářejí zejména pod vlivem různých modeli̊ a více či méně příhodných analogií a metafor, které jsou jim postupně předkládány během školní výuky ve fyzice i v chemii. $K$ tomu přirozeně přistupují i jejich předchozí představy o makrosvětě, které často přenášejí i do oblasti mikrosvěta. Protože nelze přesně odlišit zdroje vzniku žákovských představ, používáme pro jednoduchost pro označení chybných nebo nepřesných představ slovo miskoncepce. U jednotlivých představ pak v kapitole 2 diskutujeme možné zdroje jejich vzniku.

$\mathrm{Na}$ závěr ještě uved’me, že s ohledem na omezený rozsah této studie se nezabýváme miskoncepcemi, které se týkají vlastností látek v různých skupenstvích a fázovými přechody, i když tato témata $\mathrm{s}$ částicovou stavbou látek úzce souvisí.

\section{PřEDSTAVY STAROVĚKÝCH I POZDĚJŠÍCH MYSLITELŮ O STAVBĚ HMOTY}

V této kapitole předkládáme popis představ řeckých atomisti̊, přičemž se zaměřujeme na př́činy vzniku atomismu, prezentujeme nejdůležitější myšlenky, se kterými ve své teorii pracovali, a ukazujeme, k jakým představám o stavbě hmoty dospěli. Uvádíme také některé další představy (zejména Aristotelovy), které se v opozici $\mathrm{k}$ atomismu objevily a se kterými se v podobě miskoncepcí můžeme u žáků také často setkat. Závěr kapitoly je pak ukončen stručnou informací o postavení atomismu ve středověku a na počátku novověku. 


\section{1 ŘECKÝ ATOMISMUS}

Ve druhé polovině 5 . století př. n. l. se vedle již známých ohnisek rozvoje řecké vědy a filozofie (Athény, Mílétos, Efesos, Elea, Krotón) objevilo na severu země nové centrum - město Abdéra. Zde působili ve svém vrcholném období atomisté Leukippos (asi 490-asi 420 př.n. l.) a Démokritos (asi 460-asi 370 př.n.l.), kteří jsou považováni za zakladatele atomismu. Osobní podíly Leukippa a Démokrita na tvorbě představ o atomech nelze s jistotou určit, zdá se však pravděpodobné, že Leukippos byl tvůrcem základních tezí atomismu, Démokritos pak jeho teorii rozpracoval v ucelenou soustavu a aplikoval na všechny tehdy známé obory vědění (Tretera, 1996: s. 58). Máme doklady o tom, že Démokritos se zvláště intenzívně zabýval epistemologickými základy atomismu a také že vypracoval mnoho jeho detailních aplikací, např́íklad v teorii vnímání (Kirk et al., 2004: s. 518). Démokritem zároveň končí období tzv. předsókratovské filozofie a řecký atomismus představuje vyvrcholení přrírodně filozofického rázu tohoto období. Nauku atomistů později ještě rozvinul Epikúros (341-270 př. n. 1.), jehož učení shrnul Titus Lucretius Carus (97-55 př. n. l.) ve své naučné básni $O$ př́rodě (De rerum natura) (Lucretius Carus, 1971), ve které podává soustavný výklad atomismu.

\subsubsection{PŮVOD ATOMISMU}

Jak jsme již uvedli výše, pojem atomu byl ve starověku výsledkem čistě spekulativních úvah. Původ atomismu je předmětem Aristotelova ${ }^{1}$ referátu ve spise $O$ vzniku a zániku (Aristotelés, 1984: s. 90-91). Vznik atomismu vycházel zejména z potřeby vysvětlit mnohost a pohyb, které předchozí elejská škola ${ }^{2}$ považovala za nemožné. Podle Parmenida z Eleje, zakladatele elejské školy, je jsoucno ${ }^{3}$ nutně jedno a je nehybné, protože prázdno (totožné s nejsoucnem) neexistuje a pohyb a mnohost jsou bez prázdna nemožné.

Podle antických filozofů Leukippos v souladu se smyslovým vnímáním nepopírá ani vznik a zánik a také ani pohyb a mnohost jsoucen. Leukippos, stejně jako eleaté, tvrdil, že pohyb bez prázdna neexistuje, že prázdno je nejsoucno a že jsoucí neobsahuje žádné nejsoucno. ${ }^{4}$ Podle Leukippa však jsoucno není jedno, nýbrž je složeno z nekonečného počtu jsoucen, která jsou pro svůj malý objem neviditelná. Tato jsoucna se podle něho pohybují v prázdnu (které podle něho existuje) a vzájemným spojováním zpo̊sobují vznik věcí a rozkladem jejich zánik (Svoboda, 1962: s. 127) ${ }^{5}$.

Druhá myšlenka, v níž se Leukippos rozcházel s eleaty, se týkala dělitelnosti látky. Eleaté zastávali nauku o nedělitelnosti bytí. Podle Zénónovy aporie míry není totiž možné dělení látky na nekonečně mnoho částí: „Tyto části totiž bud’ mají konečnou délku a pak jejich součet musí být nekonečný, nebo nemají žádnou délku a pak jejich součet má délku nulovou." (Štoll, 2009: s. 63). Podle Zénóna však vede k rozporům jak myšlenka nekonečné dělitelnosti látky, tak myšlenka, že existuje hranice dělení (tj. jakási nejmenší velikost).

\footnotetext{
${ }^{1}$ Aristotelés ze Stageiry (384-322 př.n. l.) je všeobecně považován za největšího myslitele starověku.

${ }^{2}$ Eleaté představovali filozofickou školu, která striktně oddělovala sféru rozumového vědění a smyslového vnímání, naši zkušenost jako důkaz nepřipouštěli. Mezi hlavní představitele elejské školy patřili Parmenidés z Eleje (asi 510 př.n.l.-450 př.n.l.), Zénón z Eleje (asi 490-asi 430 př.n. l.) a Melissos ze Samu (asi 470-asi 430 př.n. 1.), které lze považovat za současníky Leukippa a Démokrita.

${ }^{3}$ Jsoucno můžeme definovat jako to, co je.

${ }^{4}$ Protože to, co je jsoucí, je jsoucno zcela plné.

${ }^{5}$ Zl. A 37 ze Simplikia.
} 
Atomisté souhlasí se Zénónem v tom, že myšlenka dělení do nekonečna je vnitřně rozporná, ale na rozdíl od Zénóna neodmítají reálnou existenci prostoru. Uvažují tak, že pokud lze těleso dělit do nekonečna, musí být též zároveň do nekonečna rozděleno (tj. možnost rozdělení se opírá o skutečnost rozdělení). Jestliže je však rozdělení skutečně do nekonečna provedeno, je otázka, co zbude. Nemůže to být bod, nebot z bodů se nic kvantitativního (rozměrného) skládat nemůže. Ale protože je nemožné, aby tělesa sestávala z pouhých bodů, musí nutně existovat části, které jsou již nedělitelné (Aristotelés, 1984: s. 64-66).

Podle Leukippa tak při dělení látky (jsoucen, věcí, těles) dojdeme až k malým částečkám, které už dále dělit nelze. Tyto částečky nazval „nedělitelnými“, tedy „atomy“ (řec. atomos = nerozřezatelný, nedělitelný). Leukippos prohlásil, že žádná z těchto částic, jichž je podle něj nekonečně mnoho, není dělitelná, nýbrž každá je pravým jsoucnem, jehož vlastnostmi jsou plnost, absence vnitřní změny a neporušitelnost (Svoboda, 1962: s. 79). ${ }^{6}$

\subsubsection{PROBLÉm PRÁZDNÉHO PROSTORU}

Jak jsme již uvedli výše, atomisté ve své teorii zavedli předpoklad prázdného prostoru (řec. kenón), který umožnil všechno to, co v parmenidovském pojetí jednoho jsoucího možné není, tj. pohyb jakožto změnu místa v prostoru, vznik a zánik jakožto skladbu a rozložení atomárních tělísek v prostoru a změnu jakožto přestrukturování takových složenin. Prostor je pro atomisty něco samostatně existujícího, je to reálný nekonečný prostor, který vytváří rámec pro všechny věci. Je statický, homogenní, spojitý (kontinuální) a nekonečný.

\subsubsection{Vlastnosti ATOMŮ}

Podle zakladatelů atomismu jsou atomy jako částice většinou tak malé, že je smysly nemůžeme vnímat, třebaže Démokritos pravděpodobně zastával názor, že „může existovat atom velikosti universa" (Kirk et al., 2004: s. 533). Atomy jsou roztroušeny po nekonečném prázdnu a jsou nekonečné co do počtu i tvarů, protože neexistuje žádný důvod, proč by měl být některý z tvarů privilegovaný (Svoboda, 1962: s. 121). ${ }^{7}$ Podle představ atomistů tak mohou být atomy kulovité, pyramidální, špičaté, oblé, zprohýbané, hranaté, tvarově nepravidelné, drsné, hladké či opatřené háčky. Mezi atomy jsou tedy určitě takové, které jsou vhodné k vzájemné kombinaci, a takové, jež se k ní nehodí. Hypotézy nekonečného množství tvarů atomů využívali atomisté k výkladu rozmanitosti smyslových jevů (Aristotelés, 1984: s. 63). Veškeré „kvalitativní“ rozdíly mezi předměty (jež jsou konglomeráty atomů) závisejí pouze na kvantitativních rozdílech mezi atomy (napřr. barvy těles jsou zpơsobeny podle atomistů různým tvarem a povrchem atomů).

Atomy byly atomisty vymezeny jako nejjemnější, tj. dále už fyzicky nedělitelné stavební kameny látky i duše. Jejich nedělitelnost zdůvodňovali jejich „plnotou“ (řec. to pléres), tj. atomy jsou nekonečně tvrdé a ani největší silou se nedají rozbít (Diogenes Laertios, 1964: s. 377). Atomy jsou podle atomistů nejen neporušitelné, tj. nedělitelné a absolutně tuhé, ale také neměnné, nevzniklé a nezničitelné a neobsahují prázdno. Démokritos předpokládal u atomů i různou tíži, která byla úměrná jejich velikosti a bylo ji možno určit odolností vůči nárazu (Aristotelés, 1984: s. 93).

\footnotetext{
${ }^{6}$ Zl. B 8 ze Simplikia.

${ }^{7}$ Zl. A 8 ze Simplikia.
} 
Atomy jsou látkově totožné, tj. neliší se druhově (jsou pouze jednoho druhu v tom smyslu, že jsou z téže látky, hmoty), liší se jen tvarem, velikostí a místem (polohou), tedy nepodstatnými geometrickými vlastnostmi. Démokritos nečiní žádný rozdíl mezi geometrickými a fyzikálními entitami, a proto ho lze právem považovat za prvního myslitele, který pro svůj výklad světa důsledně použil matematiku.

\subsection{4 Ронув АTOMŮ}

Podle atomistů se atomy pohybují v prázdném prostoru, který byl pro vysvětlení pohybu nutným předpokladem. Jsou-li totiž podle atomistů všechny atomy z téže látky a celý prostor by byl beze zbytku vyplněn touto stejnou látkou, nebyl by žádný pohyb pozorovatelný. Obě složky (atomy a prázdno) jsou věčné a neměnné, proto mezi nimi není možný přechod. Stejně věčný je i pohyb. Všechny pohyby se dějí z vnitřní nutnosti atomů, teprve při nárazech působí vnější síla druhých atomů, avšak není žádné „síly“ mimo atomy, tj. Démokritos nevysvětluje pohyb, na rozdíl např. od Aristotela, nějakou vnitřní oživující silou, vnitřní účelovostí ani vnějším impulsem prvotního hybatele.

\subsection{ODPŮRCI ATOMISTŮ}

Démokritova materialistická a mechanistická představa světa vyvolávala odpor $\mathrm{u}$ jeho oponentů, $\mathrm{k}$ nimž patřili zejména Platón (427-347 př.n. l.) a Aristotelés (384-322 př.n. l.). I v Platónově učení se můžeme setkat s jakýmisi elementárními stavebními jednotkami, kterými je pět základních živlů (oheň, země, vzduch, voda a éter). Ty se však ještě dále skládaly z miniaturních částic (mnohostěnů), jež dělitelné již nebyly. Všechny materiály na Zemi jsou pak sloučeniny čtyř elementů ohně, země, vzduchu a vody (viz dnešní čtyři skupenství látek). Z éteru, jenž se nemůže míchat s ostatními čtyřmi živly, jsou pak vytvořena nebeská tělesa (Slunce, hvězdy, ostatní planety). Podle Platóna však jednotlivé živly vytvářejí pouze hmotný svět, který je světem zdání; skutečným světem (světem pravého bytí) je svět idejí. ${ }^{8}$

Aristotelés, nejvýznamnější Platónův žák, nesouhlasil s eleaty, co se týče neexistence pohybu, ale ani $\mathrm{s}$ představami atomistů o prázdném prostoru a $\mathrm{s}$ tím, že nová kvalita může vzniknout jen přeskupením atomů. I podle něho se prvotní neurčená látka rozčleňuje na pět živlů. Tělesa jsou složena z maličkých částeček jednotlivých živlů, které se ale dají dále dělit až do jakýchsi nejmenších částí, jež jsou hustě „nasety“ bez mezer. Tyto částice pak mají vlastnosti celku, jehož jsou součástí (Aristotelés, 1996: s. 28-29). Prázdný prostor (vakuum) podle Aristotela neexistuje, nebot př́roda má z prázdného místa hrůzu (lat. horror vacui); proto se snaží každé prázdné místo okamžitě zaplnit. Prostor je podle něho vždy místo zaujímané tělesem, proto prostor bez tělesa nemůže existovat. Protože existuje více druhů živlů, může být pohyb vysvětlen bez nutné potřeby prázdného prostoru.

Aristotelés byl zároveň přesvědčen, že pohyb nelze redukovat jen na prostorové přemístování vnitřně neměnných elementů, jak se domnívali atomisté. Pohyb není pro Aristotela něco vnějšího, co se s věcí děje, nebo pouhá změna jejích vztahů, nýbrž cosi vnitřního, co vytváří a buduje věc $\mathrm{v}$ jejím bytí. Každá věc směřuje sama od sebe, ze svých vlastních potencí, k realizaci své přirozenosti, k naplnění svého bytí a v tomto smyslu je ,živá“. V tomto ohledu byla Aristotelova představa blízká původnímu řeckému chápání slova „fýsis“ („příroda“) jako toho, co „roste ze sebe

\footnotetext{
${ }^{8}$ Platón je považován za nejvýznamnějšího idealistu starověku.
} 


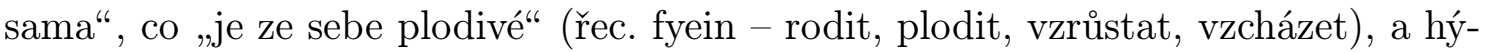
lozoistické (řec. hýlé - látka, zoé - život) představě prvních myslitelů (Thalés, Anaximandros, Anaximenés, Hérakleitos), tedy nauce o všeobecné oduševnělosti hmoty, kdy život je vlastní všem věcem přírody.

\subsection{OD ŘECKÉHO ATOMISMU K NOVOVĚKÉ VĚDĚ}

Protože atomistická nauka odporovala běžné lidské zkušenosti o spojitosti a dělitelnosti látky, upadla během středověku v zapomnění. Do popředí se dostala teorie vycházející z Aristotelových představ, podle níž se každá látka sestávala z nejmenších částeček (lat. minima naturalia) (de Vos \& Verdonk, 1996), které měly všechny vlastnosti makroskopické látky jen s tou výjimkou, že nebyly dělitelné (např. nejmenší částečka vody byla velmi malá, dále nedělitelná kapka vody).

K znovuoživení řeckého atomismu došlo až v 17. století zásluhou Pierra Gassendiho (1592-1655), ale stále se jednalo pouze o spekulace o existenci atomů, které nebylo možné nijak dokázat. Teprve John Dalton (1766-1844) na začátku 19. století odhalil zákony slučování chemických prvků, které poskytly atomové hypotéze alespoň nepřímý důkaz. Přesto ještě na začátku 20. století považoval např. Ernst Mach (1838-1916) atomy jen za jakési myšlenkové konstrukce. ${ }^{9}$ Teprve teoretická a experimentální analýza Brownova pohybu provedená na počátku 20. století byla všeobecně uznána za první nesporný důkaz částicové struktury látek.

$\mathrm{Na}$ závěr této kapitoly ještě uved’me, že stejně jako nemůžeme na současnou moderní vědu nahlížet jako na jakýsi produkt starověké filozofie, nemůžeme ani starověkou filozofii chápat po vzoru dnešní vědy. Jestliže definujeme vědu jako systém institucionalizovaných postupů a standardizovaný způsob provádění experimentů, který je spojen s určitým zpo̊sobem formulování problémů, pak Démokritovy a Leukippovy spekulace představují v moderní atomové teorii jen jakési podivné a ničím nepodložené hypotézy. Jestliže se však na vědu díváme jako na tradici kladení zajímavých otázek, pak spekulace filozofư o atomech můžeme považovat za důležitou součást tradice vědy.

\section{P̌̌EDSTAVY ŽÁKŮ O ATOMECH}

V této kapitole uvádíme přehled nejčastějších miskoncepcí v oblasti stavby hmoty, které byly identifikovány mnohými, vesměs zahraničními výzkumy. Současně prezentujeme výsledky výzkumu představ žáků 9. ročníků o atomech, který jsme provedli na několika českých školách, abychom ilustrovali míru rozššřrení těchto miskoncepcí také u našich žáků.

Jejich představy jsme zjištovali pomocí testu, který byl sestaven ze 14 úloh zaměřených na nejčastější miskoncepce $\mathrm{v}$ oblasti atomistiky (kompletní test je připojen na konci článku). Na řešení testu měli žáci přibližně 20 minut, přičemž vybírali vždy jednu odpověd' ze čtyř nabízených možností a měli také možnost doplnit u každé úlohy vlastní odpověd'. Test jsme zadali v květnu a červnu 2017170 žákům z šesti základních škol a jednoho gymnázia v Ústeckém a Moravskoslezském kraji a v Praze

\footnotetext{
${ }^{9}$ Po celé 19 . století byl při studiu fyzikálních jevů preferován makroskopický přístup, který úvahy o struktuře látek odmítal jako zbytečné a nepodložené spekulace. Tento postoj většiny tehdejších vědců byl ovlivněn převládajícím filozofickým směrem té doby - pozitivismem, který se snažil veškeré poznání zakládat pouze na tom, co je smyslově dáno. Právě Ernst Mach byl jedním z představitelů druhé fáze ve vývoji pozitivismu, tzv. empiriokriticismu.
} 
(podíl žáků z gymnázia činil 17,6 \%, což v našem souboru odpovídá 30 žákům). I když se děti seznamují s částicovou strukturou látek a s prvními modely atomu zpravidla již v 6. ročníku základní školy, učivo z atomové a jaderné fyziky je pak zařazeno zejména do 8. a 9. ročníku. Představy žáků jsme proto zjištovali na konci 9. ročníku, kdy lze již předpokládat ucelenější poznatky v této oblasti.

Nejčastější zjištěné miskoncepce jsme shrnuli do čtyř podkapitol, ve kterých komentujeme výsledky našeho výzkumu v kontextu výsledků již provedených zahraničních výzkumů, poukazujeme na možné zdroje chybných představ a zároveň u některých miskoncepcí uvádíme paralely s koncepty starověkých myslitelů. Údaje v procentech, které uvádíme u některých miskoncepcí v závorce, se týkají vždy jen výsledků zjištěných $\mathrm{v}$ našem výzkumu provedeném u českých žáků. V páté části této kapitoly uvádíme srovnání výsledků žáků základních škol a žáků z gymnázia pro několik vybraných testových položek.

\subsection{Existence A Vlastnosti ATOMŮ}

\subsubsection{EXISTENCE ATOMŮ}

Žáci se dozvídají o existenci atomů zpravidla na začátku 2. stupně základní školy. Jednoduché školní experimenty ilustrující difúzi v plynných, kapalných a pevných látkách nebo Brownův pohyb mohou pak dětem poskytnout alespoň nepřímé di̊kazy o existenci pohybujících se částic. I když si děti vytvoří představu, že atom je nejmenší stavební jednotka hmoty, mají přesto často problém porozumět jeho nepatrnosti (Harrison \& Treagust, 1996). Některé děti se např́klad domnívají, že atomy lze vidět pod mikroskopem $(5,9 \%)$ nebo dokonce i pouhým okem $(2,4 \%)$. U části žáků se lze také setkat $\mathrm{s}$ představou, že atomy vidět nemůžeme, ale můžeme pouze věrit, že existují (15,3\%). Tato „víra v existenci atomů“ může pramenit z toho, že děti se ve škole sice dozvědí, že látky mají nespojitou strukturu, ale je pro ně jednodušší tuto skutečnost přijmout jako fakt a uvěřit tomu, co ř́ká učitel, než se snažit opřít o nějaké přesvědčivější důkazy a argumenty. $\mathrm{K}$ tomu může přispívat např. i značná odlišnost vyobrazení atomů, která žáci znají z učebnic, a obrázků vytvořených např. elektronovým mikroskopem, které jsou žákům nejčastěji předkládány jako zobrazení atomů.

\subsubsection{TVAR ATOMŮ}

Děti si na základě předkládaných modelů atomů, které jsou na základní škole zobrazovány vesměs jako koule, často vytvářejí představu atomů jako pevných a tvrdých kuliček, které se nemohou rozbít na menší částice (Griffiths \& Preston, 1992; Harrison \& Treagust, 1996). I náš výzkum ukázal, že si 31,8 \% žáků myslí, že atomy mají tvar koulí, které jsou uvnitř plné. Tyto představy dětí jsou zřejmou paralelou k neporušitelným a absolutně tuhým atomům řeckých atomistů (viz podkapitola 1.1.3).

Méně často se lze u dětí setkat i s představou, že atomy jsou ploché (Griffiths \& Preston, 1992). I když výzkumy ukázaly, že výskyt této představy je u žáků spíše marginální (v našem výzkumu se jednalo o 2,9 \% žáků), může to být nechtěný důsledek dvourozměrných znázornění atomů v učebnicích nebo také ve škole používané přirovnání modelu atomu ${ }^{10}$ ke sluneční soustavě (jádro= Slunce, pohybující se elektrony $=$ planety obíhající kolem Slunce).

\footnotetext{
${ }^{10}$ Viz Rutherforův (planetární) model atomu.
} 


\subsubsection{VELIKOST ATOMŮ}

S ohledem na současnou vědu lze říci, že atom nemá žádné ostré hranice, takže velikost atomu není jasně definovaný pojem. ${ }^{11}$ Žáci však mívají často značně zkreslené představy o rozměrech atomového obalu ve vztahu k velikosti atomového jádra. Myslí si např́iklad (Harrison \& Treagust, 1996), že kdyby mělo jádro v průměru $5 \mathrm{~cm}$, elektrony by se nacházely od jádra ve vzdálenosti v rozmezí od 2 až $10 \mathrm{~mm}$ do $50 \mathrm{~cm}$ (ve skutečnosti je to přibližně $5 \mathrm{~km}$ ). Někdy si dokonce myslí, že se elektrony jádra dotýkají; proto do svých úvah o velikosti atomu elektronový obal ani nezahrnují a myslí si, že velikost atomu určuje pouze počet protonů a neutronů v jádře atomu $(22,4 \%)$. Př́činou těchto zkreslených představ může být jednak záměna hmotnosti jádra za jeho velikost (atomové jádro má velkou hmotnost ve srovnání s hmotností elektronů, ale jeho rozměry jsou 100000 krát menší než rozměry elektronového obalu) a zároveň to může být důsledek modelů atomů používaných v učebnicích, které vesměs neznázorňují rozměry atomového jádra a obalu ve správném poměru.

Poměrně rozšířená je i představa (Unver \& Arabacioglu, 2015), že všechny atomy jsou stejně velké, ale vytvářejí různě velké molekuly (20,6 \%). Podobná, i když méně rozšǐřená představa (Griffiths \& Preston, 1992) je, že ve vesmíru existuje pouze jeden základní druh atomu, ze kterého jsou vytvářeny všechny složitější atomy $(2,9 \%)$. Někteří žáci zřejmě vnímají atomy jako jakési uniformní stavební jednotky, ze kterých se vytvářejí složitější celky (např. molekuly), jež se teprve pak od sebe navzájem liší.

\subsubsection{HмотNost ATOMŮ}

Podobně uniformně vidí někteří žáci i hmotnost atomů, tj. myslí si, že všechny atomy jsou částice se stejnou hmotností $(6,5 \%$ ). Lze se setkat i s představou (Karataş et al., 2013), že v různých stavech látky mají stejné atomy (resp. molekuly) různou hmotnost, například že atomy v plynech, např. ve vodní páře, jsou lehčí než atomy v pevné fázi, např. v ledu. Objevuje se ale i představa (Driver, 2003), že atomy plynů nemají žádnou hmotnost (4,1\%). Tyto představy souvisejí s tím, že žáci často přenášejí vlastnosti makroskopických těles na oblast mikrosvěta, jak bude ještě dále podrobněji komentováno.

Časté je i zaměňování pojmu atomu a molekuly (Karataş et al., 2013). O tom svědčí představa zjištěná i v našem výzkumu, že hmotnost atomu závisí na tom, z kolika jednodušších atomů je vytvořen $(20,6 \%)$.

Co se týče hmotnosti samotných elementárních částic, vzhledem k jejich nepatrnosti si děti někdy myslí, že nemají žádnou nebo mají zápornou hmotnost (Driver, R. et al., 2006). Zjištěna byla i miskoncepce, že hmotnost protonu je jeden gram (Griffiths \& Preston, 1992), což zřejmě souvisí s představou, že elementární částice musí mít nějakou jednotkovou hmotnost.

\subsubsection{DALŠí Vlastnosti ATOMŮ}

Pro děti je velmi obtížné odpoutat se od viditelného světa, který mohou běžně vnímat svými smysly. Pokud mají uvažovat o něčem tak nepatrném a pro ně těžko představitelném, jako jsou atomy, je pro ně nejjednodušší jim připsat vlastnosti, které znají z makrosvěta (Driver, 2003). Děti si např́íklad často myslí, že atomy

\footnotetext{
${ }^{11}$ Místo velikosti atomu můžeme uvažovat vzdálenost mezi dvěma atomovými jádry (resp. jejich centry) v pevné látce nebo v kapalině.
} 
pevných těles mají všechny nebo většinu makroskopických vlastností, které jsou jinak spojovány s pevnými látkami. Následkem toho děti přisuzují jednotlivým atomům (spíše než skupině atomů) vlastnosti jako tvrdost, teplotu, barvu atd. V našem výzkumu jsme se např. setkali s představou, že atom zlata je lesklý, podobně jako se lesknou věci ze zlata $(4,7 \%)$, nebo že atom zlata je tvrdý, protože zlato je tvrdé $(2,4 \%)$. Podobné představy lze najít i u Aristotela, který také přisuzoval nejmenším částicím, ze kterých se tělesa skládají, vlastnosti těchto těles (viz podkapitola 1.3).

Podobně si také žáci myslí, že atom je pružný a může se proto stlačit nebo natáhnout a pak se zase vrátit do původního tvaru (Harrison \& Treagust, 1996). V našem výzkumu jsme žákům položili otázku, co se stane s atomy, když se s nimi srazí rychle se pohybující vlak. 31,2 \% z nich zvolilo odpověd', že „vzduch je pružný, proto jsou i atomy ve vzduchu pružné, mohou se tak snadno stlačit a při srážce s vlakem se nerozbijí".

\subsection{POHYB ATOMŮ A PRÁzDNÝ PROSTOR}

Holding (1987) ve své studii ukázal, že se představy žáků v rozmezí od 8 do 17 let postupně mění od kontinua přes kousky kontinua až po naučenou vědeckou reprezentaci částic. Přesto má až $20 \%$ sedmnáctiletých žáků stále představu hmoty jako spojitého prostředí. Přitom má více studentů představu kontinua v prŕpadě kapalin než plynů (Novick \& Nussbaum, 1981). Podobně Renström et al. (1990) ve svém výzkumu zjistil, že žáci ve věku 13 až 16 let používají až šest kvalitativně odlišných představ o stavbě látky. Liu a Lesniak (2005) uvádějí, že se jednotlivé koncepce o stavbě látek u dětí nevyvíjejí postupně (tj. že by jedna nahrazovala druhou), nýbrž spíše v jakýchsi překrývajících se vlnách, ve kterých mohou vedle sebe koexistovat navzájem konfliktní pohledy (tj. žáci mohou např. používat různé představy pro různá skupenství).

Velmi častý model, který děti ve svých úvahách použivají, jsou atomy jakožto malé kousky hmotné substance nebo konečné kousky materiálové substance, které dostaneme postupným dělením materiálu (Driver, 2003). Mohou to být např́klad malé kousky pevného tělesa nebo malé kapky kapaliny. Tyto kousky mohou mít různou velikost a tvar, není mezi nimi žádný prázdný prostor a mají stejné vlastnosti jako materiál, který vytvářejí. Taková představa se ukázala i v našem výzkumu. Někteři žáci si např́klad mysleli, že po odstranění všech atomů z listu papíru zůstane ještě maličký kousek papíru o velmi malé hmotnosti (7,7 \%). I tyto miskoncepce jsou zřejmou paralelou $\mathrm{k}$ Aristotelovým představám, který předpokládal, že tělesa jsou složena z maličkých částeček, které se dají dělit až do jakýchsi nejmenších částí, mezi nimiž ale není žádný prázdný prostor (viz podkapitola 1.7).

V tomto kontextu se také objevuje velmi častá miskoncepce, že mezi atomy musí být nějaká látka, která prostor mezi nimi vyplňuje. Tou bývá např. vzduch (nebo také kyslík, případně jiné plyny), různé materiály nebo i elektrické náboje (Griffiths \& Preston, 1992). Tato miskoncepce patří k těm nejrozšǐřenějším, což se potvrdilo i v našem výzkumu. 39,4 \% žáků uvedlo, že kousek zlata je tvořen atomy zlata a látkou, která vyplňuje prostor mezi atomy zlata, nebo že po odstranění všech atomů z listu papíru zůstane trochu papírového prachu $(19,4 \%) .{ }^{12}$ Koncepce jakési „mateřské substance“ se dobře ukazuje i v představě některých žáků, kteří

\footnotetext{
${ }^{12} \mathrm{U}$ otázky č. 11 jsme žákům nabídli dvě podobné možnosti, tj. že po odstranění atomů papíru zůstane maličký kousek papíru, nebo papírový prach. V našem výzkumném souboru téměř třikrát více žáků zvolilo druhou možnost. U této otázky se dobře ukázala, podobně jako u otázky 7 , představa „mateřské substance“, která často přetrvává i u starších žáků a studentů.
} 
si myslí, že při zahřrivání železné tyče bude zvětšovat svioj objem sama tyč, ale velikost atomů a vzdálenost mezi nimi se měnit nebude $(17,1 \%)$. Tato miskoncepce je spojena s představou atomů železa nacházejících se v nějakém „materiálu“ (např. „železu“), který se sám roztahuje (tj. roztažnost je vlastnost pouze makroskopického materiálu). V zahraničních výzkumech (Allen, 2014) se ukázalo, že když mají děti nakreslit např. měd', nakreslí cosi jako „hrozinkovou bulku“, v níž jsou atomy mědi usazeny jako v jakémsi měděném lơžku (tzv. rozinkový model).

Z výše uvedeného je vidět, že žáci mají nepochybně problém porozumět koncepci prázdného prostoru, a jak ukázaly zahraniční výzkumy (Karataş et al., 2013), je tomu tak zejména v př́ipadě plynů, v menší míře i u kapalin. V př́ípadě pevných látek si žáci často myslí, že atomy se nemohou pohybovat vůbec (Ozmen, 2011), protože mezi částicemi $\mathrm{v}$ pevné látce nejsou žádné mezery $(22,9 \%)$. Poměrně rozšiřrená je i představa, že se v pevné látce atomy pohybovat nemohou, pohybují se pouze elektrony $\mathrm{v}$ atomových obalech $(20,0 \%)$.

\subsection{ZMĚNY ATOMŮ}

V několika otázkách jsme zjištovali, co si žáci myslí o možných změnách atomů, jestliže jsou podrobeny různým procesům. Ptali jsme se např́klad, co se stane s atomy uhlíku, když kousek uhlí roztlučeme kladivem. I v tomto př́padě byl zřejmý silný vliv přenosu toho, co se děje s kouskem uhlí, tj. makroskopickým materiálem, na atomární úroveň. Častá odpověd’ byla, že od některých atomů uhlíku odpadnou malé části, takže se tyto atomy zmenší (20,0 \%). Dále se objevila představa, že když se uhlí rozpadne na prach, atomy se také rozpadnou (11,8\%). Podobně se podle dětí některé atomy ve vzduchu rozbijí na menší části, když do nich narazí dostatečně rychle jedoucí vlak $(7,7 \%)$. Je zřejmé, že někteří žáci v 9 . ročníku nemají dobrou představu o energii, která je potřebná k rozbití atomu, a také nemají jasno, jakým způsobem se může uskutečnit změna atomu jednoho prvku na atom jiného prvku. V našem výzkumu se žáci přikláněli i $\mathrm{k}$ takovým přičinám přeměny atomů na jiné atomy, jako je působení slunečního světla $(6,5 \%)$ nebo přítomnost hřmění a blýskání $(6,5 \%)$.

Poměrně častá je i představa, že elektron je jednou ze základních částic, z nichž se atom skládá, a když je elektron od atomu odtržen, atom se rozdělí (15,9\%). $\mathrm{V}$ našem výzkumu jsme se také setkali s několika miskoncepcemi, které přisuzují jedinečnost jednotlivým elementárním částicím v atomu (viz např. představa, že se atomy nemohou přeměňovat, protože každý z protonů, neutronů a elektronů v atomu je jedinečný $(22,9 \%))$.

Mnoho miskoncepcí se také týká elektronového obalu, který děti často vnímají jako cosi tvrdého, co je třeba rozbít, abychom mohli elektron z atomového obalu odstranit (Harrison \& Treagust, 1996). Lze se např. setkat s představou elektronového obalu, který funguje podobně jako skořápka, která chrání ořech $(5,3 \%)$. Někteř́ žáci si pak dokonce myslí, že elektrony nemohou být z atomu odtrženy vůbec $(8,2 \%)$. Při používání termínu „elektronový obal“ bychom proto měli být velmi obezřetní, pozornost žáků bychom měli směřovat spíše $\mathrm{k}$ hladinám nebo pozicím jednotlivých elektronů.

\subsection{ANIMISMUS}

Miskoncepce týkající se animismu, tj. představy, že atom je živý (má vlastnosti živých organismů), patří $\mathrm{k}$ těm nejrozšířenějším (Griffiths \& Preston, 1992). I v našem výzkumu odpovědi tohoto typu představovaly v součtu přibližně $28 \%$. Konkrétně 
se jednalo o tři představy - atomy mohou růst a dělit se $(13,5 \%)$; živé jsou pouze atomy živých organismů (8,8 \%); a atomy jsou živé, protože se pohybují (5,9\%). Kromě těchto miskoncepcí se lze také setkat s představou, že atomy se mohou snadno dělit, a tak se reprodukovat, a také že pouze neživé věci jsou složeny z atomů, ale živé věci jsou tvořeny z rostlinných nebo živočišných buněk (Harrison \& Treagust, 1996).

Zajímavé jsou také představy dětí o tom, co se stane s atomy po smrti. Velmi častá představa je, že když živočich zemře, atomy se rozštěpí na jednodušší části a ty pak vytvoří nové atomy (47,7 \%). Podobné výsledky ukázal i výzkum TIMSS (Palečková et al., 1997), který se v České republice uskutečnil v roce 1995. Kromě této nejrozššřrenější představy si také žáci myslí, že atomy přestanou existovat, jakmile se živočich rozloží $(21,2 \%)$, nebo že se atomy po smrti živočicha přestanou pohybovat $(8,8 \%)$. V souhrnu představují odpovědi týkající se miskoncepcí spojených se změnou atomů po smrti (rozpad, zánik nebo zastavení pohybu atomů) téměř $78 \%$, což je poměrně závažné zjištění.

Výše uvedené miskoncepce spojené s animismem souvisí s tím, že žáci zaměňují atomy a buňky, protože atomy mají podobně jako buňka také jádro a obal, který jádro chrání (viz odpověd’ jednoho žáka: „Zviřre, které zemře, tak se pomalu rozkládá a mizí, stejně tak atomy v jeho těle.“). Někdy si také žáci myslí, že jádro kontroluje „aktivity“ atomu (Harrison \& Treagust, 1996). Jedná se o tzv. interferenci v přenosu učení (v tomto případě se jedná o tzv. negativní interferenci), děti se nejprve ve výuce setkávají s buňkou a to, co se o ní dozvědí, přenášejí jednoduše také na atomy.

Animistické představy žáků jsou konzistentní se starořeckým názorem o všeobecné oduševnělosti hmoty (hýlozoismus) a částečně také s Aristotelovou představou substance, která je subjektem své vlastní činnosti. Při výuce je proto třeba jasně rozlišovat mezi jádrem buňky a jeho funkcemi a jádrem atomu a zdůrazňovat zejména významné odlišnosti atomu a buňky (např́klad, že elektrony netvoří pevný obal kolem jádra nebo že atom po smrti živočicha nezaniká).

\subsection{SROVNÁNí VÝSLEDKŮ ŽÁKŮ ZÁKLADNÍCH ŠKOL A VÍCELETÉHO GYMNÁZIA U VYBRANÝCH OTÁZEK Z TESTU}

Jak bylo uvedeno v úvodu této kapitoly, v našem výzkumném souboru bylo zahrnuto také 30 žáků jedné kvarty víceletého gymnázia. I když ve výzkumném souboru výrazněji převažovali žáci základních škol, bude zajímavé i užitečné porovnat relativní četnosti odpovědí žáků ze základní školy a žáků z gymnázia. Výsledky tohoto srovnání je však třeba brát jen jako orientační vzhledem k nepř́liš rozsáhlému souboru gymnaziálních žáků.

S ohledem na omezený rozsah článku jsme za tímto účelem vybrali pět otázek z testu (otázky č. 2, 3, 7, 8 a 11), u kterých jsme zaznamenali významnější rozdíly mezi oběma sledovanými skupinami žáků. Relativní četnosti odpovědí prezentujeme pro názornost ve formě grafů (obr. 1 až 5). Písmeno „„“ představuje volbu „Jiná odpověd"“, tj. žáci mohli v testu napsat vlastní odpověd'. V grafech uvádíme také relativní četnosti př́padů, kdy žáci na otázku vůbec neodpověděli (označeno zkratkou „neřeš.").

OTÁZKA Č. 2: JSOU ATOMY ŽIVÉ? (OBR. 1)

U této otázky mohli žáci vybírat z těchto nabízených odpovědí: (a) Ano, protože atomy mohou růst a dělit se.; (b) Ne, atomy nemají vlastnosti živých organismů.; 


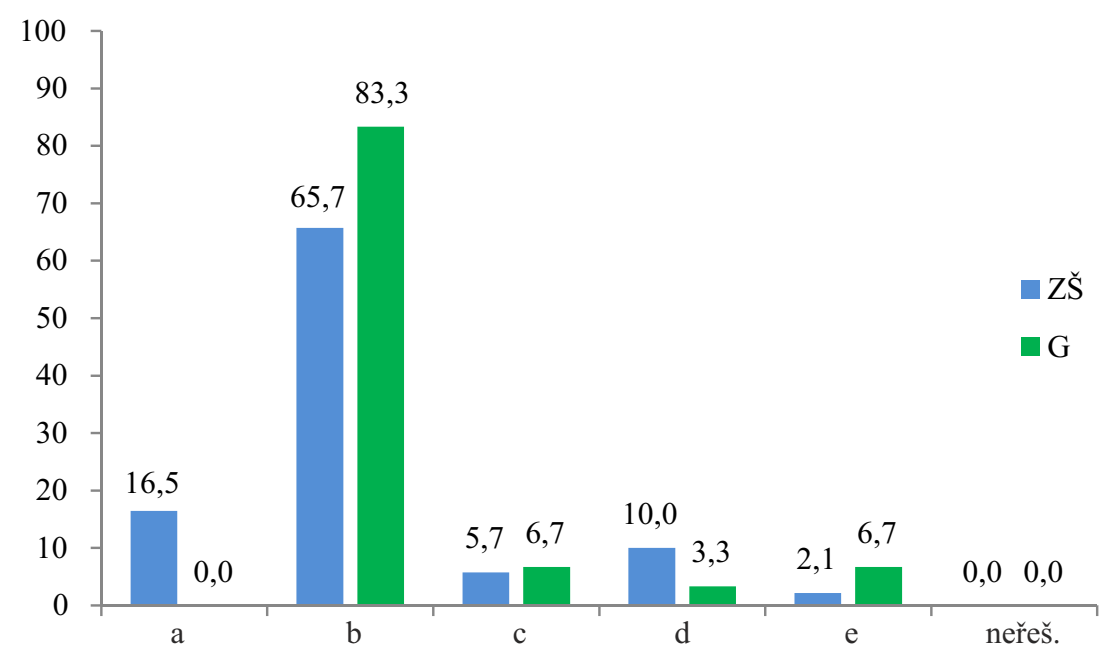

Obr. 1: Relativní četnosti odpovědí žáků v procentech na otázku č. 2

(c) Ano, atomy jsou živé, protože se pohybují.; (d) Živé jsou pouze atomy živých organismů. Za nejpřijatelnější lze označit odpověd' (b). ${ }^{13}$

Poměrně značný rozdíl v relativních četnostech jsme zaznamenali u odpovědi (a). Zatímco z gymnaziálních žáků si tuto možnost nevybral nikdo, u žáků ze základních škol byla druhou nejčastější odpovědí. U těchto žáků má poměrně silné zastoupení i podobná představa (d). Z porovnání relativních četností u jednotlivých odpovědí je zřejmé, že animistické představy jsou rozššřené zejmena u žáků základních škol. Učitelé však často o těchto představách u svých žáků nevědí, nebot podobné otázky žákům kladou jen zřídka. Jak se ale v našem výzkumu ukázalo, je velmi důležité žákům opakovaně zdůrazňovat odlišnosti atomu a buňky, jak to bylo již uvedeno $\mathrm{v}$ kapitole 2.4 .

OTÁZKA Č. 3: ŽIVOČICHOVÉ SE SKLÁDAJÍ Z MNOHA ATOMŮ. CO SE S TĚMITO ATOMY STANE POTOM, CO ŽIVOČICH ZEMŘE? (OBR. 2)

U této otázky mohli žáci vybírat z těchto nabízených odpovědí: (a) Atomy se přestanou pohybovat.; (b) Atomy se vrátí zpět do prostředí.; (c) Když živočich zemře, atomy se rozštěpí na jednodušší části a ty pak vytvoří nové atomy.; (d) Atomy

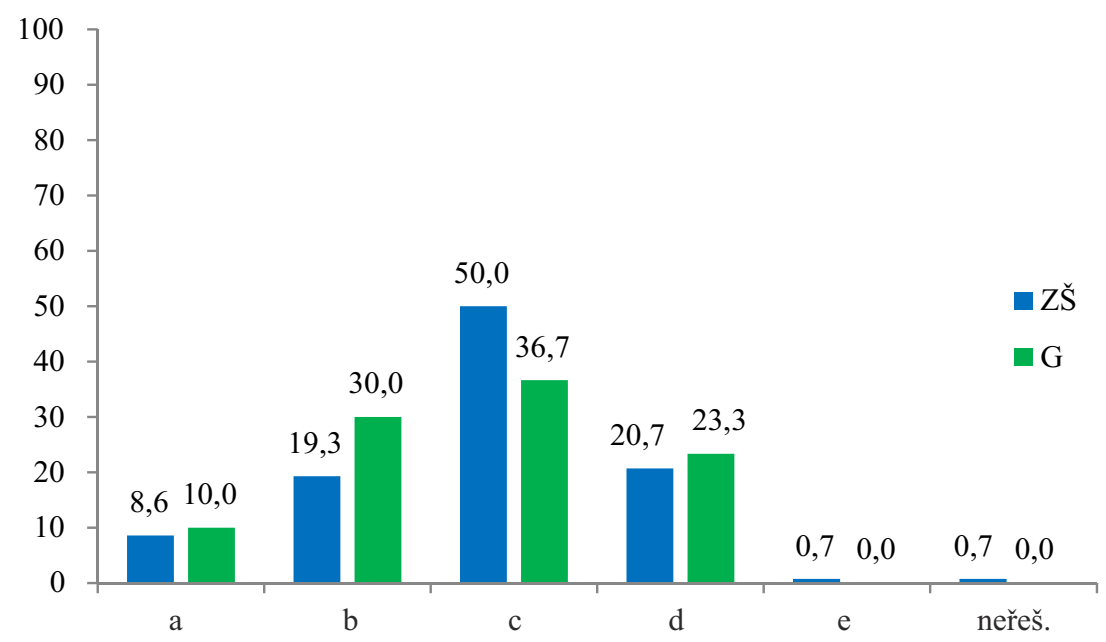

Obr. 2: Relativní četnosti odpovědí žáků v procentech na otázku č. 3

\footnotetext{
${ }^{13} \mathrm{~S}$ ohledem na možné zkomplikování situace různými úvahami neoznačujeme odpověd’ jako správnou, ale jako (z vědeckého hlediska) „nejpřijatelnější“.
} 
přestanou existovat, jakmile se živočich rozloží. Za nejpřijatelnější lze označit odpověd' (b).

Největší rozdíl v relativních četnostech jsme zaznamenali zejména u odpovědi (c). Tato nesprávná představa je silně zastoupena jak u žáků gymnázia, tak u žáků ze základních škol, kde tuto možnost zvolila dokonce polovina žáků. Tato častá miskoncepce byla komentována také již v kapitole 2.4. Je zajímavé, že další dvě časté představy, (a) a (d), se u obou skupin vyskytují se zhruba srovnatelnou četností, přičemž téměř čtvrtina gymnaziálních žáků si myslí (více než je tomu u žáků ze základních škol), že atomy přestanou existovat, jakmile se živočich rozloží.

I v případě této otázky se lze domnívat, že se podobná otázka běžně ve škole neklade a žáci tak při výběru pro ně nejpřijatelnější odpovědi nejspíše jednoduše přenášejí své zkušenosti z běžného života i na „osud“ atomů po smrti živočicha (tj. uvažují o jejich zániku nebo rozkladu).

\section{OTÁZKA Č. 7: MÁ ATOM ZLATA NĚKTERÉ STEJNÉ VLASTNOSTI JAKO MALÝ KOUSEK ČISTÉHO ZLATA? (OBR. 3)}

U této otázky mohli žáci vybírat z těchto nabízených odpovědí: (a) Ano, zlato je tvrdé, a atom zlata je proto také tvrdý.; (b) Ne, jednotlivý atom zlata nemá stejné vlastnosti jako kousek zlata.; (c) Ano, atom zlata je lesklý, podobně jako se lesknou věci ze zlata.; (d) Ne, protože kousek zlata je tvořen atomy zlata a látkou, která vyplňuje prostor mezi atomy zlata. Za nejpřijatelnější lze označit odpověd' (b).

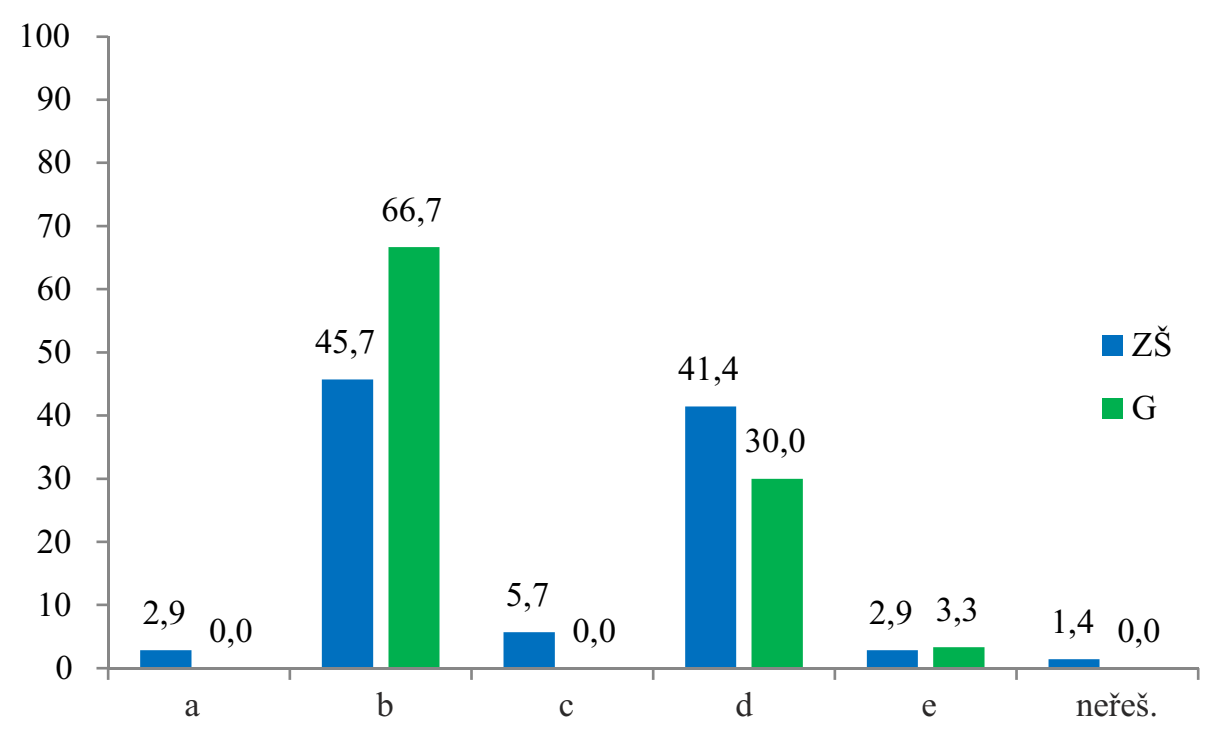

Obr. 3: Relativní četnosti odpovědí žáků v procentech na otázku č. 7

Výrazný rozdíl v četnostech odpovědí jsme zaznamenali u odpovědi (d). Tato nesprávná představa zároveň patří $\mathrm{k}$ těm nejsilnějším u obou skupin žáků. $\mathrm{O}$ této časté miskoncepci jsme se zmiňovali již v kapitole 2.2. Přestože v rámci běžné výuky nejsou podobné otázky zpravidla diskutovány, je důležité, aby učitel nesprávné představy svých žáků poznal a snažil se je korigovat. Je také zajímavé, že představy (a) a (c) se u žáků 9. ročníků vyskytly již jen ve velmi malé míře.

\section{Otázka Č. 8: Pohybují se atomy v pevné látce? (oBr. 4)}

U této otázky mohli žáci vybírat z těchto nabízených odpovědí: (a) Ano, atomy v pevné látce kmitají.; (b) $\mathrm{Ne}$, nemohou se pohybovat, protože mezi částicemi 


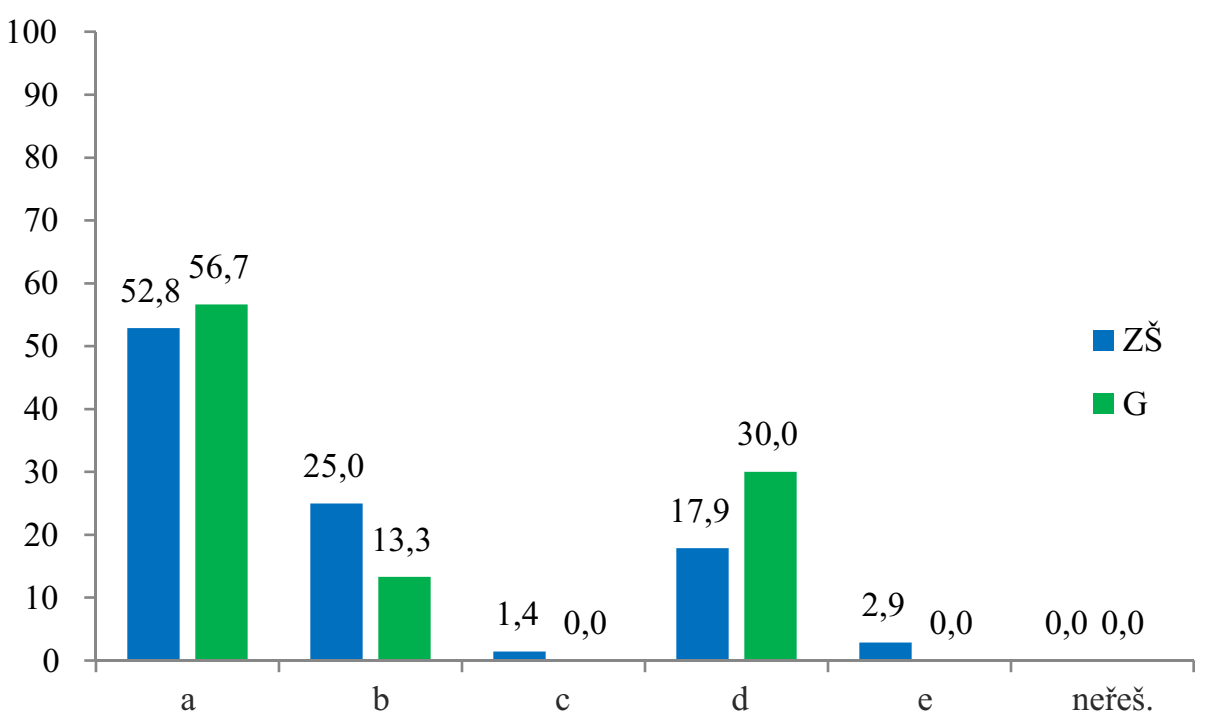

Obr. 4: Relativní četnosti odpovědí žáků v procentech na otázku č. 8

v pevné látce nejsou žádné mezery.; (c) Ne, nemohou se pohybovat, protože atomy pevné látky jsou těžké.; (d) Ne, atomy se nepohybují, pohybují se jen elektrony v atomových obalech. Za nejpřijatelnější lze označit odpověd' (a).

Otázka č. 8 se týkala běžné znalosti, se kterou se setkají všichni žáci na základní škole. Typické chybné odpovědi žáků jsme již okomentovali v kapitole 2.2. Zajímavé je, že úspěšnost žáků v obou skupinách je zhruba srovnatelná. U této otázky se však ukázaly výrazné rozdíly v četnostech u odpovědí (b) a (d). Výraznější podíl chybné představy (b) u žáků základních škol bychom mohli zřejmě vysvětlit intuitivní potřebou žáků „vyplnit“ atomy veškerý prostor. Překvapivá je však výrazná převaha chybných odpovědí (d) u gymnaziálních žáků, kteří přisuzují pohyb jen elektronům, nikoliv samotným atomům. Pro učitele to může být významný signál, že je důležité aktivně propojovat nové poznatky s těmi předchozími, tj. mluví-li se o struktuře atomu (zpravidla podrobně právě v 9. ročníku), žáci zpravidla vnímají atom jako nehybný, v němž se pohybují jen elektrony. To, co se učili o skupenstvích látek a tepelných jevech (zpravidla v 8. ročníku), jsou poznatky, které si s novými nedokáží dostatečně propojit. U gymnaziálních žáků je tato skutečnost výraznější, nebot se zpravidla při hledání správných odpovědí méně často uchylují k miskoncepcím (to je zřejmé z analýzy ostatních otázek v testu), naopak se více opírají o poznatky, které získali v rámci školní výuky.

OTÁZKA Č. 11: PřEDSTAV SI, ŽE BYCHOM ODSTRANILI VŠECHNY ATOMY LISTU PAPÍRU. Co BY POTOM ZŮSTALO? (OBR. 5)

U této otázky mohli žáci vybírat z těchto nabízených odpovědí: (a) Zůstane trochu papírového prachu.; (b) Nezůstane nic.; (c) Zůstane jen maličký kousek papíru o velmi malé hmotnosti.; (d) Zůstane energie. Za nejpřijatelnější lze označit odpověd' (b).

Výrazný rozdíl v četnostech odpovědí jsme zaznamenali zejména u odpovědi (a). Zároveň tato nesprávná představa patří k těm nejsilnějším u obou skupin žáků, přičemž u žáků gymnázia je tato volba překvapivě výrazně četnější. Nevíme sice přesně, co si žáci představují pod „papírovým prachem“, ale na základě toho, co bylo již uvedeno v kapitole 2.2, se lze domnívat, že děti očekávají, že po odstranění atomů listu papíru „něco zbude“. To koresponduje s relativní četností odpovědi (d) 


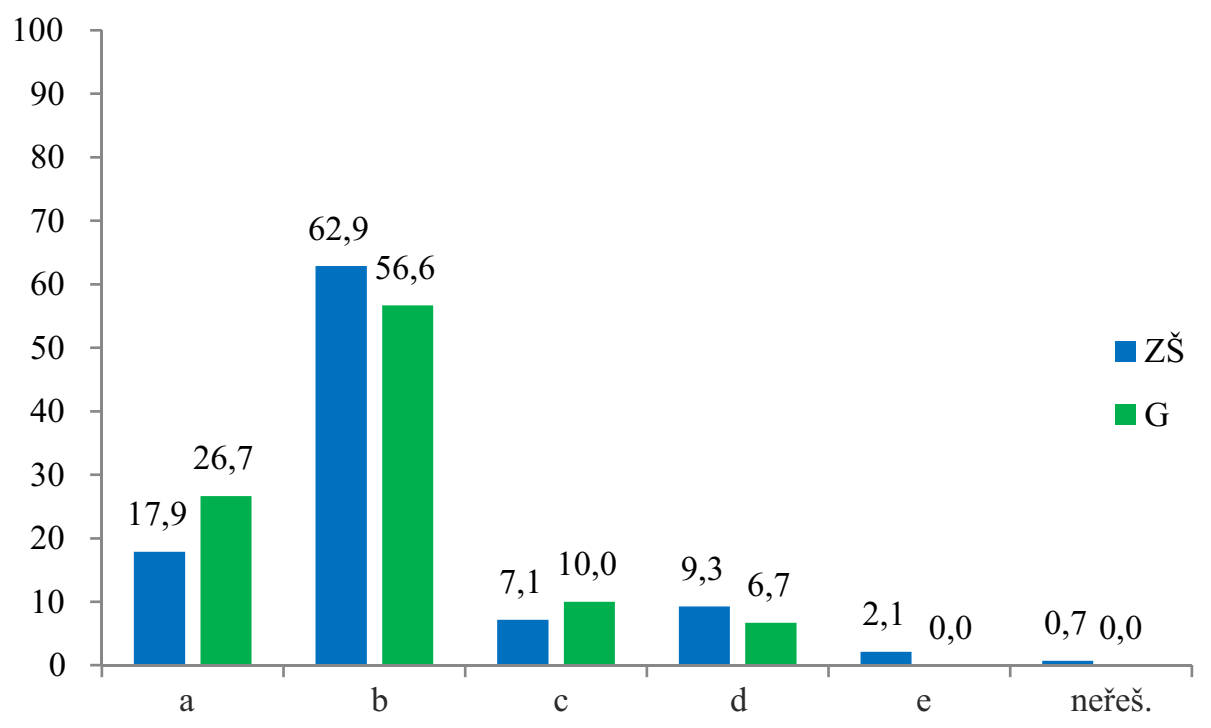

Obr. 5: Relativní četnosti odpovědí žáků v procentech na otázku č. 11

u otázky č. 7, která byla zaměřena na podobnou častou mylnou představu. V grafu na obr. 5 si lze všimnout, že u ostatních odpovědí (včetně té nejpřijatelnější) se četnosti zásadněji neliší. I tato otázka je nezvyklá, ve škole zpravidla nebývá pokládána, a je zřejmé, že poměrně značná část žáků nemá v této věci jasno. Pro učitele to opět může být zajímavý námět $\mathrm{k}$ diskuzi se žáky, kteří si přitom mohou ujasnit některé důležité skutečnosti týkající se struktury látek.

\section{Diskuse A ZÁVĚR}

V naší studii jsme ukázali nejčastější miskoncepce týkající se stavby hmoty, se kterými se mohou učitelé na všech stupních škol u svých žáků a studentů setkat. Různé modely a analogie, které učitelé při výkladu pojmu atomu běžně používají, jsou často složité a značně abstraktní, proto si žáci na jejich základě nevytvářejí zcela správné představy. Ačkoliv se děti snaží po absolvování výkladu o atomech sladit své představy s těmi vědeckými, realita je často taková, že si vytvoří nějaký vlastní alternativní model, který lépe vyhovuje jejich předchozím zkušenostem s tím, jak svět okolo nich funguje.

Představy žáků, které by byly v souladu s těmi vědeckými, se obvykle neutvářejí tak rychle, jak by to vyžadovalo tempo výuky. Mnoho žáků, zejména na základní škole, nemá ještě dostatečně rozvinutou formální úroveň myšlení a prostorovou představivost, aby dokázalo do hloubky porozumět výukovým modelům a různým analogiím, které učitel použivá, a také nedokáže odlišit, co model ukazuje správně a co ne (Stepans, 2003). Některé rysy modeli̊ atomu děti pak přenášejí na samotné atomy (např. atom je barevný, má ohraničený obal apod.) nebo si představují elektronový obal jako oblak dýmu, ve kterém jsou usazeny elektrony jako kapky vody v mraku (Harrison \& Treagust, 1996). Přričinu těchto představ lze hledat i v učebnicích (ale i jiných výukových materiálech, at už tištěných či elektronických), ve kterých jsou žákům předkládány dvourozměrné, nejčastěji barevné, modely atomu, jež se navíc často od sebe liší. Různost těchto modelů pak může v žácích vyvolat otázku, který model je vlastně správný a přesný.

Mnohé dětské představy, se kterými se u žáků setkáváme, se nám někdy mohou zdát zbytečně složité a někdy až poněkud bizarní. Děti ale při své cestě za 
poznáváním a pochopením okolního světa nevycházejí z jednoduchých předpokladů a experimentů, na kterých staví moderní věda. Na vše, co mohou vnímat svými smysly, aplikují často svá pravidla, která jim připadají přirozená a v jejich očích dobře fungují. Právě znalost tohoto zdánlivého paradoxu nám může pomoci vést žáky složitým procesem učení, při kterém se mohou postupně přiblížit k pochopení tak komplikovaného mikrosvěta.

Kromě vlastních představ žáků však bývá zdrojem miskoncepcí i nevhodně pojatá výuka. Proto správné výukové techniky mohou účinně pomáhat při budování správných představ o mikrosvětě. Je třeba poznamenat, že představy o atomech, které jsme v článku diskutovali, vycházejí z klasické fyziky, přičemž miskoncepce nižší úrovně jsou zpravidla nahrazovány miskoncepcemi vyšší úrovně (viz kap. 2), resp. představami, které jsou nejbližší skutečnosti (např. orbity elektronů v obalu atomu jsou nahrazeny orbitaly, v nichž elektrony nevykonávají klasický pohyb, tj. nemají definovanou polohu ani rychlost). Nelze se domnívat, že nesprávné představy žáků lze jednoduše rozbít a nahradit těmi správnými. Vzhledem ke složitosti mikrosvěta se jako nejvhodnější jeví „cesta postupného modelování“ (Mandíková \& Trna, 2011), nebot je zřejmé, že si žáci nemohou vytvořit představu správného fungování mikrosvěta najednou, nýbrž postupně a přiměřeně jejich schopnostem chápat modelové a abstraktní představy.

Na počátku výuky fyziky (nebo i přírodovědy) by měly děti například vědět, že atomy jsou tak malé, že jsou mimo možnosti našich smyslů. Starší žáci by pak měli získat povědomí o tom, že chování částic v mikrosvětě je odlišné od chování věcí, které známe z běžné zkušenosti. Proto si vytváříme různé představy, tj. modely, přičemž každý takový model celkem výstižně popisuje nějaké vlastnosti atomu (resp. aspekty jeho chování), ale něco vždy zachycuje chybně. Žáci by si měli uvědomit, že na atom nebo částice $\mathrm{v}$ atomu se však nemůžeme jednoduše „podívat" a vidět přesně to, co zobrazují modely atomu, že nemůžeme jejich chování popsat běžnými pojmy, které používáme pro popis makrosvěta, a že poznání světa atomů je vždy zprostředkované na základě nějakého experimentu.

\section{LITERATURA}

Allen, M. (2014). Misconceptions in primary science. Maidenhead: Open University Press.

Aristotelés (1984). Cllověk a př́roda. Praha: Svoboda.

Aristotelés (1996). Fyzika. Praha: Petr Rezek.

Ayas, A., Özmen, H. \& Çalik, M. (2010). Students' conceptions of the particulate nature of matter at secondary and tertiary level. International Journal of Science and Mathematics Education, 8(1), 165-184.

de Vos, W. \& Verdonk, A. H. (1996). The particulate nature of matter in science education and in science. Journal of Research in Science Teaching, 33(6), 657-664.

Diogenes Laertios (1964). Životy, názory a výroky proslulých filosofů. Praha: NČSAV.

Driver, R. et al. (2003). Making sense of secondary science. New York: Routledge Falmer.

Feynmann, R.P., Leighton, R. B. \& Sands, M. (2000). Přednášky z fyziky s řešenými př́klady 1. Praha: Fragment. 
Griffiths, A. K. \& Preston, K.P. (1992). Grade-12 students' misconceptions relating to fundamental characteristics of atoms and molecules. Journal of Research in Science Teaching, 29(6), 611-628.

Harrison, A. G. \& Treagust, D. F. (1996). Secondary students' mental models of atoms and molecules: Implications for teaching chemistry. Science Education, 80(5), 509-534.

Holding, B. (1987). Investigation of schoolchildren's understanding of the process of dissolving with special reference to the Conservation of matter and the development of atomistic ideas [Thesis]. Leeds: University of Leeds.

Chalmers, A. (2009). The scientist's atom and the philosopher's stone: How science succeeded and philosophy failed to gain knowledge of atoms. Dordrecht: Springer.

Karataş, F., U̇nal, S., Durland, G. \& Bodner, G. (2013). What do we know about students' beliefs? Changes in students' conceptions of the particulate nature of matter from pre-instruction to college. In G. Tsapralis \& H. Sevian (Eds.), Concepts of matter in science education (231-248). Dordrecht: Springer.

Kirk, G. S., Raven, J. E. \& Schofield, M. (2004). Předsókratovští filosofové. Praha: Oikoymenh.

Lacina, A. (2011). Cásticová struktura látek ab initio I. Matematika, fyzika, informatika, $20(6), 350-355$.

Liu, X. \& Lesniak, K. (2005). Understanding the matter concept from elementary to high school. Science Education, 89(3), 433-450.

Lucretius Carus, T. (1971). O prírodě. Praha: Svoboda.

Mandíková, D. \& Trna, J. (2011). Žákovské prekoncepce ve výuce fyziky. Paido: Brno.

Maunová, K. (2010). Žákovské představy a pojetí učiva [Rigorózní práce]. Plzeň: Západočeská univerzita.

Novick, S. \& Nussbaum, J. (1981). Pupils' understanding of the particulate nature of matter: A cross-age study. Science Education, 65(2), 187-196.

Ozmen, H. (2011). Turkish primary students' conceptions about the particulate nature of matter. International Journal of Environmental ES Science Education, 6(1), 99-121.

Palečková, J., Tomášek, V. \& Straková, J. (1997). Třetí mezinárodní výzkum matematického a přírodovědného vzdělávání (Výsledky žákư 7. a 8. ročníkio Přírodovědné předměty). Praha: ÚIV.

Rámcový vzdělávací program pro základní vzdělávání (RVP ZV). (2010). Česká republika. Dostupné z http://www.nuv.cz/file/133

Renström, L., Anderson, B. \& Marton, F. (1990). Students conceptions of matter. Journal of Educational Psychology, 82(3), 555-569.

Stepans, J. (2003). Targeting students'science miskonceptions. Tampa: Showboard.

Svoboda, K. (Ed.). (1962). Zlomky předsokratovských myslitelů. Praha: NČSAV.

Škoda, J. \& Doulík, P. (2006). Výzkum dětských pojetí vybraných přírodovědných fenoménů z učiva fyziky a chemie na základní škole. Pedagogika, 56(3), 231-245.

Stoll, I. (2009). Dějiny fyziky. Praha: Prometheus.

Tretera, I. (1996). Nástin dějin evropského myšlení. Praha: COWI. 
Unver, A. O. \& Arabacioglu, S. (2015). Helping pre-service science teachers to understand atomism through observations and experiments. Journal of Baltic Science Education, 14(1), 64-84.

Eva HeJnovÁ, eva.hejnova@ujep.cz

Univerzita J. E. Purkyně v Ústí nad Labem, Př́rodovědecká fakulta

Katedra fyziky

České mládeže 8, 40096 Ústí nad Labem, Ceská republika

DALIBOR HeJnA, dalibor.hejna@tul.cz

Technická univerzita v Liberci, Fakulta př́rodovědně-humanitní a pedagogická Katedra filozofie

Univerzitní náměstí 1410/1, 46117 Liberec, Česká republika 


\section{TEST - POROZUMĚNÍ POJMU ATOM ${ }^{14}$}

\section{POKYNY K VYPLNĚNÍ TESTU}

- Vyber vždy jen jednu odpověd’ u každé části otázky nebo napiš svoji vlastní.

- Tvoje odpověd' by měla vyjadřovat to, co si sám myslíš.

- Na vyplnění testu máš přibližně 20 minut.

1. Můžeme jednotlivé atomy vidět?
a) Ano, atomy jsou dost velké na to, abychom je mohli vidět pod běžným mikroskopem.
b) Ne, atomy nelze vidět, můžeme pouze věřit, že existují.
c) Ano, velké atomy lze vidět i pouhým okem.
d) Ano, atomy můžeme vidět, ale pouze pomocí speciálního labo- ratorního přistroje.
e) Jiná odpověd'

\section{Jsou atomy živé?}
a) Ano, protože atomy mohou růst a dělit se.
b) Ne, atomy nemají vlastnosti živých organismů.
c) Ano, atomy jsou živé, protože se pohybují.
d) Živé jsou pouze atomy živých organismů.
e) Jiná odpověd'

3. Živočichové se skládají z mnoha atomů. Co se s těmito atomy stane potom, co živočich zemře?
a) Atomy se přestanou pohybovat.
b) Atomy se vrátí zpět do prostředí.
c) Když živočich zemře, atomy se rozštěpí na jednodušší části a ty pak vytvoří nové atomy.
d) Atomy přestanou existovat, jakmile se živočich rozloží.
e) Jiná odpověd'

4. Jaký mají atomy tvar?
a) Atomy mohou mít různý tvar podle druhu látky, kterou tvoří (mohou být třeba kulaté, vejčité, protáhlé apod.).
b) Atomy mají tvar koulí, které jsou uvnitř plné.
c) Atomy jsou ploché (jako když rozplácneme kuličkuz modelíny).
d) O atomu lze pouze říci, že má kladné jádro a elektronový obal.
e) Jiná odpověd'

5. Mají všechny atomy stejnou velikost?

a) Nemají, protože velikost atomu určuje počet protonů, neutronů a elektronů, z nichž je atom složen.

b) Mají, protože ve vesmíru existuje jen jeden základní druh atomu, ze kterého jsou vytvářeny všechny složitější atomy.

\footnotetext{
${ }^{14}$ Nejpřijatelnější odpověd' je u každé otázky vyznačena tučným písmem.
} 

c) Nemají, protože velikost atomu určuje pouze počet protonů a neutronů $\mathrm{v}$ jádř̀ atomu.
d) Všechny atomy jsou stejně velké, ale vytvářejí různě velké molekuly.
e) Jiná odpověd'

6. Mají všechny atomy stejnou hmotnost?
a) Ne, protože atomy plynů nemají žádnou hmotnost.
b) Ne, protože hmotnost atomu závisí na tom, z kolika jednodušších atomů vytvořen.
c) Ano, všechny atomy jsou částice se stejnou hmotností.
d) Ne, protože atomy mají různý počet protonů, neutronů a elek- tronů.
e) Jiná odpověd'

7. Má atom zlata některé stejné vlastnosti jako malý kousek čistého zlata?
a) Ano, zlato je tvrdé, a atom zlata je proto také tvrdý.
b) Ne, jednotlivý atom zlata nemá stejné vlastnosti jako kousek zlata.
c) Ano, atom zlata je lesklý, podobně jako se lesknou věci ze zlata.
d) Ne, protože kousek zlata je tvořen atomy zlata a látkou, která vyplňuje prostor mezi atomy zlata.
e) Jiná odpověd’

8. Pohybují se atomy vevné látce?
a) Ano, atomy v pevné látce kmitají.
b) Ne, nemohou se pohybovat, protože mezi částicemi v pevné látce nejsou žádné mezery.
c) Ne, nemohou se pohybovat, protože atomy pevné látky jsou těžké.
d) Ne, atomy se nepohybují, pohybují se jen elektrony v atomových obalech.
e) Jiná odpověd'

9. Zvětší se atomy v železné tyči, když ji budeme zahřivat?
a) Při zahřívání tyče se budou zvětšovat pouze jádra atomů.
b) Při zahřívání tyče se budou uvolňovat elektrony z atomových jader a atomy se tak zvětší.
c) Při zahřívání tyče se zvětší vzdálenost mezi atomy a rozsah jejich kmitání.
d) Při zahřívání zvětšuje svůj objem pouze sama tyč, velikost atomů a vzdá- lenost mezi nimi se nemění.
e) Jiná odpověd’

10. Uhlí je tvořeno atomy uhlíku. Co se stane s atomy uhlíku, když kousek uhlí roztlučeme kladivem na prach?
a) Atomy uhlíku se nijak nezmění.
b) Nárazy kladivem způsobí změnu velikosti atomů.
c) Když se uhlí rozpadne na prach, atomy se také rozpadnou. 

d) Od některých atomů uhlíku odpadnou malé části, takže se tyto atomy zmenší.
e) Jiná odpověd'

11. Představ si, že bychom odstranili všechny atomy listu papíru. Co by potom zůstalo?
a) Zi̊stane trochu papírového prachu.
b) Nezůstane nic.
c) Zi̊stane jen maličký kousek papíru o velmi malé hmotnosti.
d) Zůstane energie.
e) Jiná odpověd’

12. Co se stane s atomy ve vzduchu, když se s nimi srazí rychle se pohybující vlak?
a) V okamžiku srážky chrání atomy jejich pevné obaly, podobně jako sko- řápka chrání ořech.
b) Vzduch je pružný, proto jsou i atomy ve vzduchu pružné, mohou se tak snadno stlačit a při srážce s vlakem se nerozbijí.
c) Jestliže je rychlost vlaku dostatečně velká, některé atomy ve vzduchu se při srážce rozbijí a rozpadnou se na menší části.
d) Při srážce s vlakem se atomy nijak nezmění.
e) Jiná odpověd’

13. Musí být atom rozbit, aby se z něj uvolnil elektron?
a) Ne, elektron se může odtrhnout bez rozbití atomu.
b) Elektron je jednou ze základních částic, z nichž se atom skládá. Když je elektron od atomu odtržen, atom se rozdělí.
c) Ne, stačí rozbít pouze obal atomu.
d) Elektrony nemohou být z atomu odtrženy.
e) Jiná odpověd'

14. Jak se mohou atomy jednoho prvku přeměnit na atomy jiného prvku?
a) Příčinou přeměny atomů na jiné atomy je sluneční světlo.
b) Nestabilní atomy se mohou samovolně změnit na jiné atomy při radioaktivním rozpadu.
c) Atomy se nemohou přeměňovat, protože každý z protonů, neutronů a elek- tronů $\mathrm{v}$ atomu je jedinečný.
d) Atomy se mohou změnit na jiné atomy při takových jevech jako je hřmění a blýskání.
e) Jiná odpověd' 